\title{
Improvement of Nitrogen Removal in Lab Scale Waste Stabilization Ponds and it's Applications Towards Full Scale Ponds
}

\author{
Dhanesh N. De S. Gunatilleke, Dr. Peter Van Der Steen and Prof. Huub Gijzen
}

\begin{abstract}
Global population is expected to increase significantly stretching the existing sanitation facilities to its limits. It is therefore imperative that new and economical treatment methods are developed if the people are to remain healthy. The most common processes involve utilizing natural systems. However, the main disadvantage of engaging natural systems for wastewater treatment (ponds, wetlands) is the large area requirement. Main cause for this is that the pond environment is minimally engineered. An approach to improve the overall Ammonia and Nitrogen removal rates in Waste Stabilization Pond (WSP) systems is by providing bio-film attachment surfaces. Initial tests on continuous flow experiments conducted on $8 \mathrm{~cm}$ deep lab scale facultative type WSP showed that the algal/bacterial bio-film was capable of achieving 56\% to $65 \% \mathrm{NH} 4+-\mathrm{N}$ removal and $30 \%$ to $33.5 \%$ of COD removal. Batch incubations carried out with the bio-film-coated plates under fully aerobic/ lighted conditions, an average Ammonia removal rate of $11.6 \mu \mathrm{gNH4}+-\mathrm{N} / \mathrm{cm}^{2} / \mathrm{h}$ was achieved.
\end{abstract}

Key words: Algae; Ammonia; bio-film; Nitrogen; ponds

\section{Introduction}

According to the World Health Organization (WHO, 2003), water, hygiene and sanitation interventions reduce diarrhoea incidence by $26 \%$ and mortality by $65 \%$.

Waste stabilization ponds (WSP) are one of the low cost means to achieve the above objectives in situations where land price is inexpensive, climate favourable, and a simple method of treatment that does not require equipment and operating skill is desired.

WSP, the simplest of all wastewater treatment techniques available to treat sewage, involves holding the wastewater in shallow ponds for an adequate detention period to enable the natural stabilization of organic matter to occur through microbial decomposition. The major drawback of natural systems for wastewater treatment (ponds, wetlands) is the large area requirement (under tropical conditions $>2.5 \mathrm{~m}^{2} /$ capita; compared to activated sludge $<0.5 \mathrm{~m}^{2} /$ capita) (Vander Steen, 2004). One of the reasons is that the pondenvironment is minimally engineered. Additionally, the hydraulic patterns in the pond and the environmental conditions ( $\mathrm{pH}, \mathrm{DO})$ are not controlled. Furthermore, there is none or hardly any surface for bacteria attaçhment. Bacterial flocks are also not formed, thus their number in the pond water is very low ('microbiological desert').

At present the National Water Supply \& Drainage Board, Sri Lanka (NWSDB) operates three WSPs namely in; Kataragama sacred city in operation since 1983, Mattegoda housing scheme - functioning from late $80^{\circ} \mathrm{s}$ and the most recent at Hikkaduwa - commissioned in February 2006. The Central Engineering Consultancy Bureau (CECB) has also constructed WSPs around the island.

Nitrogen removal from wastewater has been the subject of several studies during the last decade due to increasingly stringent environmental legislation in many countries. Uncontrolled release of nitrogen to the environment is assumed to cause serious pollution problems. High nitrate levels in water can cause infant methaemoglobinaemia or "blue baby syndrome", which leads to breathing difficulties and in extreme cases, death by suffocation.

Eng. Dhanash N. De S. Ounatilleke B.Sc. Eng. (Honsh, P.C. Dip. MSC CEng., MIE (SL), MCIVEM (UK) Chief Englneer, (Planning \& Design

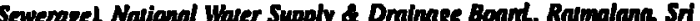
Lankn \& Former MSt, student UNESCO. IHE. Delt, Nethertands.

D. Paer Ven Der Sreen, Lecturer in mastewater inewment, UNESCO. IHE, DelA. Nethertands. Prof. Huub Gilzen, Professor of Envinowmental Biorechndosy. UNESCO IHE, Delf, Netherlands.

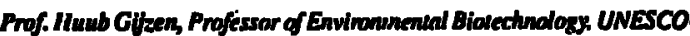
IHE, Delf, Nethertend. 
Therefore, before the treated wastewater is released to the water bodies it is essential to maintain the quality of the water to avoid further degradation of the environment since water-borne diseases from surface waters continue to be a major cause of illness.

Nitrate pollution in surface water and ground water has been attributed to wastewater outfalls and agricultural runoff. Many rivers now contain $>10 \mathrm{mg} / 1$ NO3-N and some occasionally exceed 50mg/1 NO3-N (Horne, 1995). Nitrogen as well as Phosphorous plays a major role in eutraophication (Horne and Goldman, 1994). Besides, Ammonia is toxic to aquatic organisms, especially the higher forms such as fish, at concentrations as low as $0.5 \mathrm{mg} / 1$ (Barnes and Bliss, 1983). Current mainstream technologies for wastewater treatment, such as the activated sludge process with $\mathrm{N}$ and $\mathrm{P}$ removal, are too costly to provide satisfactory solutions for the growing wastewater problems in developing regions (Gijzen and Ikramullah, 1999). Waste stabilisation pond systems are inexpensive and are well known for their ability to substantially remove pathogens and organic pollutants. However, N-removal in WSP has not been in great detail. (Zimmo et al., 2003).

Most micro organisms have the tendency to stick to a surface (substratum), not only because it offers them a protective microenvironment, but also because of nutritional advantages. In the microenvironment of a surface, nutrient levels may be much higher than they are in the bulk solution. This phenomenon can greatly affect the rate of microbial metabolism. On the surface microbial numbers and activity will usually be much greater than in free water due to adsorption effects. A surface may also be a nutrient itself, such as a particle of organic matter, where attached micro-organisms catabolise organic or inorganic nutrients directly from the surface of the particle. Dead plant material, for example, is rapidly colonised by micro organisms in soil (Lubberding, 2003).

Studies of microbial colonisation of surfaces have shown that most micro organisms grow on surfaces enclosed in bio-films. These are encased micro-colonies of bacterial cells attached to a surface by way of adhesive polysaccharides excreted by the cells. Bio-films trap nutrient for growth of the enclosed microbial population and help to prevent detachment of cells on surfaces in flowing systems. It is evident that the organisation into a complex bio-film structure protects the individual cell from many adverse environmental effects: bio-films in fixed bed reactors are highly resistant to substrate shock loads or to $\mathrm{pH}$ fluctuations, but also to antibacterial treatments like chlorination (Lubberding, 2003).

Generally, waste stabilization pond systems are considered to be ineffective in Nitrogen removal, since Nitrogen is converted from one form to another. The Nitrogen incorporated in algae (typical formulae C106H81045N16P) is settled due to sedimentation at the outlet end and subsequently demineralised. Only few attempts have been made to increase the efficiency in Nitrogen removal by further engineering of the pond environment. The best example is the provision of a bio-film support surface for enhancing the Nitrifier concentration.

The aims of this study are to;

- Study the effect of biofilm supports immersed in pond environment

- Carryout Nitrogen mass balance

- Determine the nitrification rates $\left(\mu \mathrm{g} / \mathrm{cm}^{2} / \mathrm{h}\right)$ that can be achieved by an algal-bacteria biofilm attached to biofilm support material inserted in a lab scale pond reactor.

- Carryout batch test experiments exposing biofilm plates to different $\mathrm{NH} 4+-\mathrm{N}$ concentrations to see trend in nitrification

- Propose a simple procedure to carry out batch test

- Study the type of organism/algae attached to the biofilm

This paper presents the experimental programme carried out to operate the lab scale ponds with and without bio-film supports to determine the performance of Nitrification and also to immerse bio-film plates in batch reactors to ascertain the nitrification rate that could be achieved using bio-film plates.

\section{Materials and Methods}

\subsection{Continuous Flow Experiment}

The experimental facility used in the study consisted of four PVC grey trays, each having 
nominal capacity of 16 litres. Each tray (tank) was $550 \mathrm{~mm}$ long, $370 \mathrm{~mm}$ wide, and with minimum water depth of $80 \mathrm{~mm}$. All bio-film supports have been roughened to prevent biofilm slough off from the plate. Two equally spaced baffle plates made out of Acrylate glass with smooth surface were placed in each tank to create plug flow conditions in all tanks. Florescent lamps were installed over the lab scale ponds to simulate the lighting conditions in the field. Bio-film support material was fabricated out of Acrylate glass, each $80 \mathrm{~mm}$ wide, $60 \mathrm{~mm}$ deep and $5 \mathrm{~mm}$ thick with 60 numbers per tank. A framework was installed at the bottom, without touching the tank bottom, supported on baffle plates in these two tanks to keep the bio-film plates suspended vertically in each tank with their top $5 \mathrm{~mm}$ below the water surface and their bottom edge $10 \mathrm{~mm}$ above the tank floor. Two tanks without plates were operated as controls while two tanks operated with bio-films.

All tanks were initially filled with canal water, which was screened with $300 \mu \mathrm{m}$ sieve to seed algae and microbial population. Finally all tanks were seeded with enriched culture of Nitrifiers to introduce Nitrifier population in ponds.

\section{Operating procedure:}

Following parameters were either allowed to change or remain constant in the lab environment;

1. Temperature- this was allowed to fluctuate along with lab environment but remained more or less between $18.5-21.5^{\circ} \mathrm{C}$.

2. $\mathrm{pH}$ - this was also allowed to change along with the conditions expected due to algae activity in the ponds but adequately buffered by $\mathrm{NaHCO} 3$ present in artificial wastewater to prevent inhibition.

3. Hydraulic retention time- HRT of 5 day was maintained in all reactors.

4. Influent composition- Artificial wastewater was preferred against natural wastewater in experimental set up. Typical influent composition is given in table 1 and 2.

5. Mlumination- all tanks were illuminated for twelve hours per day with a light intensity of 85 to $95 \mu \mathrm{E} / \mathrm{m}^{2} / \mathrm{s}$ throughout the ponds.
A timer was used to switch the illumination on and off.

6. Dissolved Oxygen- aeration was achieved only by algal photosynthetic activity and allowed to fluctuate according to algal activity of the ponds.

During the study all natural processes such as oxidation of organic matter, Ammonia volatilisation, Nitrification, denitrification, biological growth, and sedimentation was allowed to occur. The weekly analysis includes NH4+-N, NO2-N, NO ${ }^{3}-\mathrm{N}$ and COD using filtered samples.

Table 1. Influent Composition

\begin{tabular}{|l|l|}
\hline Component & $\begin{array}{l}\text { Concentration } \\
\text { (mg/1) }\end{array}$ \\
\hline $\mathrm{CH} 3 \mathrm{COONa3H2O}$ & 389 \\
$\mathrm{NaHCO3}$ & 113 \\
(NH4)2HPO4 & 94.5 \\
(NH4)2SO4 & 47 \\
$\mathrm{NH} 4 \mathrm{Cl}$ & 114.7 \\
$\mathrm{KH} 2 \mathrm{PO} 4$ & 66 \\
$\mathrm{Na2HIPO4.2H2O}$ & 21.3 \\
MgSO4.7H2O & 59.4 \\
CaCl2.2H2O & 59.41 \\
Micro nutrient solution & $0.3 \mathrm{ml} / 1$ \\
(see table 2) & \\
\hline
\end{tabular}

Analysis of Kjeldahl-N was carried out a few times once the reactors became stable. Biological activities were monitored through the measurement of $\mathrm{pH}$, and $\mathrm{DO}$ at least twice within a week in four places of each reactor namely; inlet, end of the first baffle, end of the second baffle and outlet.

Table 2. Micro Nutrient Solution

\begin{tabular}{|l|l|}
\hline Nutrient Solution & Dosage $(\mathrm{g} / \mathrm{l})$ \\
\hline EDTA & 10 \\
$\mathrm{FeCl} 3.6 \mathrm{H} 2 \mathrm{O}$ & 1.5 \\
$\mathrm{H} 3 \mathrm{BO} 3$ & 0.15 \\
$\mathrm{CuSO} 4 . \mathrm{H} 2 \mathrm{O}$ & 0.03 \\
$\mathrm{KI}$ & 0.18 \\
$\mathrm{MnCl2.4H2O}$ & 0.12 \\
$\mathrm{Na2M} \mathrm{M} O 4.2 \mathrm{H} 2 \mathrm{O}$ & 0.06 \\
$\mathrm{ZnCl2.7H2O}$ & 0.12 \\
$\mathrm{CoCl} 2.6 \mathrm{H} 2 \mathrm{O}$ & 0.15 \\
\hline
\end{tabular}




\subsection{Batch Experiment}

The experimental facility used in the study consisted of 13 numbers of 1.0 litre glass beakers which had a circular opening sufficient to immerse the $80 \mathrm{~mm} \times 60 \mathrm{~mm}$ bio-film plates horizontally. The beakers were placed near the lab scale ponds to provide the same light intensity as for the ponds. Artificial wastewater with different concentrations was used to expose bio-film plates. Prior to all batch tests, artificial wastewater and the demineralised water was aerated until supersaturated. Just before the test they were mixed together to achieve the planned NH4+-N concentrations. Ammonium concentrations used were approximately $60 \mathrm{mg} / 1$ (undiluted-same as artificial wastewater feeding the pond system), $25 \mathrm{mg} / \mathrm{l}$ and $10 \mathrm{mg} / \mathrm{l}$ respectively. Three bio-film plates were exposed from each of the first 3 rows for test 1 and same for the batch test 2 except that the plates were used from the middle compartment. Three plates were also exposed for $25 \mathrm{mg} / 1$ with addition of Nitrification inhibitor 2-Chloro-6-(trichloromethy) pyridine (TCMP). $3 \mathrm{mg} / 300 \mathrm{ml}$ of TCMP was added to inhibit Nitrification as per the recommendations given in the BOD test (Standard Methods). Only one side of all bio-film plates $(8 \mathrm{~cm} \times 6 \mathrm{~cm})$ were left with bio-film exposed for fully lighted condition by scraping off the bio-film that developed on the bottom and all edges with the aid of a glass slide. All beakers were filled up to $300 \mathrm{ml}$ with required Ammonium concentration. Then the plates were carefully immersed, to prevent any disturbances to the bio-film with the bio-film coated surface facing the light. A $5 \mathrm{ml}$ sample was carefully extracted at time steps of $0 \mathrm{~min}, 30 \mathrm{~min}, 1 \mathrm{hr}, 2 \mathrm{hr}, 3 \mathrm{hr}, 4 \mathrm{hr}, 5 \mathrm{hr}, 6 \mathrm{hr}, 7 \mathrm{hr}$ and $8 \mathrm{hr}$ from each batch test. DO and $\mathrm{pH}$ were noted every hour to ensure that the conditions remained aerobic while $\mathrm{pH}$ remained in the desired range to prevent any inhibition. All samples were immediately kept in the refrigerator at $4^{\circ} \mathrm{C}$. Nitrite was measured within 24hrs while Ammonium and Nitrate was followed within a week. One blank plate was also used along with 12 bio-film plates to explain the possibilities of any reaction that could happen in the absence of a bio-film.

After the last sample was taken (i.e. 8hr) the biofilm in each beaker was carefully removed and filtered. The bio-film that remained in the filter paper was dried in the oven at $105^{\circ} \mathrm{C}$ for $24 \mathrm{hrs}$ to calculate Total Suspended Solids.

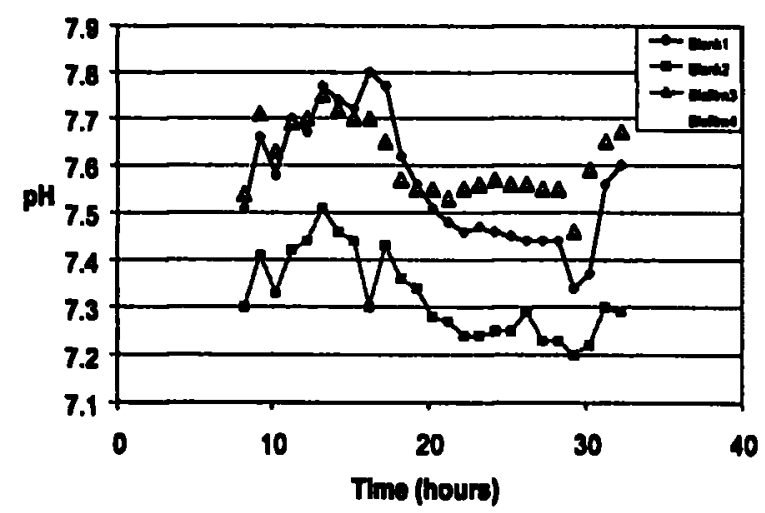

Figure 1. pH Variation with Time on 26th - 27th January 2005

\section{Results and Discussion}

\section{General}

The impact of the type of wastewater used in the experiment, biological parameters and the results obtained for Ammonium Nitrogen, Nitrite Nitrogen and Nitrate Nitrogen for continuous flow experiment and the batch test are discussed.

\section{Wastewater}

In this study it was decided to use artificial wastewater in lieu of natural wastewater and the positive and the negative impact of the selection is discussed below;

- Artificial wastewater ensures that the influent wastewater characteristics to the lab scale ponds remain more or less constant throughout the research period. However on the other hand natural wastewater characteristics can change drastically with weather condition especially in case of combined sewerage system during rainy season and dry season.

- Large storage to keep under refrigeration and transportation required to bring the wastewater from Hoek van Holland is eliminated.

- The algae and the microorganisms that will thrive under artificial wastewater may be different from the natural wastewater. 
- The natural .wastewater contains suspended solids compared to artificial wastewater and the sediment layer will be completely different. However, the experiment under review simulates a facultative pond, which will receive settled wastewater from an anaerobic pond. Hence the differences are insignificant.

- Ammonium Nitrogen and the COD in the influent were kept around $60 \mathrm{mg} / 1$ and $260 \mathrm{mg} / 1$ respectively to keep in line with the concentration of medium strength natural wastewater reaching facultative waste stabilization ponds (FWSP) in operation.

- It was fairly easy to achieve the desired $\mathrm{pH}$ in the influent with the use of $\mathrm{NaHCO}$ buffer. In pilot scale or prototype installation to control this will not be that flexible.

- By employing one common influent tank the consistency of influent quality was maintained. Further, artificial wastewater was prepared for requirements of two days and the excess amount was kept under refrigeration to prevent any activity.

\section{pH variation for continuous flow experiment}

The cumulative $\mathrm{pH}$ measurement near the inlet of both bio film reactors was about 7.8 while it gradually decreases along the plug flow reactor to 7.1 near the outlet while for the two blanks the change is from 7.6 to 7.4 which is more or less constant.

From Figure 1 it is evident that $\mathrm{pH}$ increased slightly after the illumination was switched on at 5AM (2500hours on 27th January) and decreased after 5PM (1700hours on 26th January) after illumination was switched off. Further it is also clearly visible from this graph that the $\mathrm{pH}$ is higher in biofilm reactors than in the blanks. This reflects that algal/bacterial activity is intense in biofilm reactors than the blanks, which was in fact foreseen.

\section{DO variation for continuous flow experiment}

From the Figure 2 it is clear that DO increased slightly after the illumination was switched on at 5AM (2500hours on 27th January) and decreased after 5PM (1700hours on 26th January) after the illumination was switched off. This graph shows DO will increase as a result of algal photosynthesis in the presence of light.

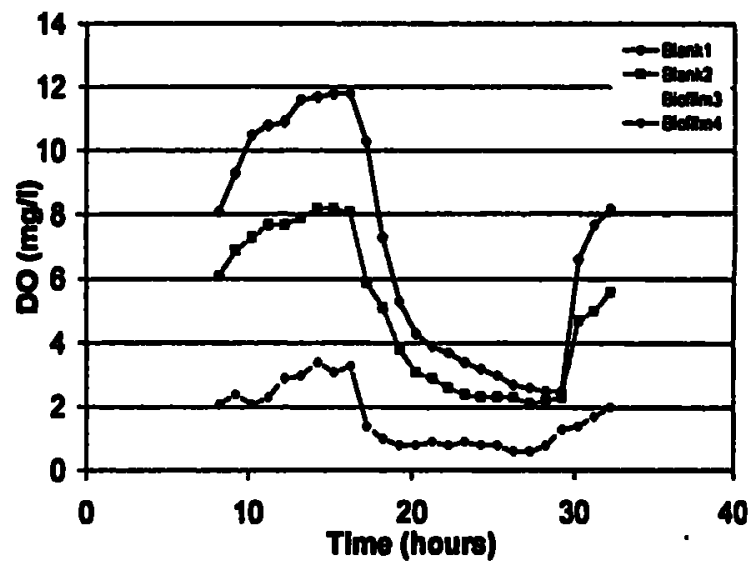

Figure 2. DO Variation with Time on 26th - 27th January 2005

\section{COD removal}

Table 3 below shows the COD removal efficiencies of all reactors

Table 3. COD removal efficiency

\begin{tabular}{|c|c|c|c|c|c|}
\hline \multirow[t]{2}{*}{ Date } & \multirow{2}{*}{$\begin{array}{c}\text { Influent } \\
\text { Conc. } \\
\text { (mg/L) }\end{array}$} & \multicolumn{4}{|c|}{$\begin{array}{l}\text { COD removal } \\
\text { efficiency }(\%)\end{array}$} \\
\hline & & Bla.1 & Bla.2 & Bio.3 & Bio. \\
\hline $24 / 11 / 2004$ & 183.8 & 26.7 & 25.8 & 15.8 & 45 \\
\hline $30 / 11 / 2004$ & 170.7 & - & 51 & 43.3 & 29.8 \\
\hline $22 / 12 / 2004$ & 276.7 & 14 & 43.6 & 37 & 41.2 \\
\hline 05/01/2005 & 267.2 & 30.8 & 32.3 & 27.1 & 38.8 \\
\hline $12 / 01 / 2005$ & 248.1 & 23.1 & 28.9 & 21.6 & 31.7 \\
\hline $18 / 01 / 2005$ & 269.4 & 34.3 & 20.6 & 26 & 43.8 \\
\hline \multicolumn{2}{|l|}{ Average } & \multicolumn{2}{|c|}{30.10} & \multicolumn{2}{|c|}{33.43} \\
\hline \multicolumn{2}{|c|}{ Standard Deviation } & \multicolumn{2}{|c|}{10.35} & \multicolumn{2}{|c|}{9.55} \\
\hline
\end{tabular}

\section{Ammonium removal}

\section{Continuous flow experiment}

The two biofilm reactors are performing better in Ammonium removal compared to that of the two blanks. On average, the two biofim reactors remove more than $60 \% \mathrm{NH} 4+-\mathrm{N}$ but the difference with the blanks are not significant.

However, when the biofilm that has developed on blank 2 was removed and put in to operation then the efficiency of removal had dropped by about $17 \%$ compared to blank 1 , which is considerable. Therefore it is clear that the removal efficiencies for the two blanks are 
almost the same until this change was implemented on 28th of January 2005 and it was immediately reflected on the analysis done on 2nd February 2005. Therefore, it can be concluded that the blanks also performed equally well in removing $\mathrm{NH} 4+-\mathrm{N}$ because of the biofilm developed on the bottom and sidewalls proved to be effective.

\section{Batch test:}

It is clear from results that the nitrification rate increases with increasing initial NH4+-N concentration. Furthermore, this relationship is linear from initial $\mathrm{NH}_{4}+-\mathrm{N}$ concentration range of $10 \mathrm{mg} / 1$ to $60 \mathrm{mg} / 1$.

It is apparent that the TCMP inhibitor concentration of $3 \mathrm{mg} / 300 \mathrm{ml}$, which is used for the BOD test, proved to be ineffective in preventing nitrification. The only major difference in the two tests is that the BOD test was carried out in a closed bottle at $20^{\circ} \mathrm{C}$ for 5 days in the dark while the batch test was carried out in fully lighted open conditions with artificial wastewater saturated with $D O$.

\section{Discussion in relation to the research objectives}

- Effect of biofilin supports immersed on pond environment:

More biomass and algae, along with sunlight to the ponds, increases $\mathrm{DO}$ and $\mathrm{pH}$ due to intense algal photosynthesis. This was clearly visible in figures 1 and 2 when the timer for the lights was on and off during the 24hour readings taken on 26th and 27th of January 2005. On the other hand, more biomass containing more nitrifying organisms will consume more DO for Nitrification as well as to stabilize organic matter, which will be represented by BOD and COD.

- Comparison of nitrification rate with pilot scale and full scale ponds;

Average nitrification rate per pond per $\mathrm{m}^{2}=$ $15555 \mathrm{mgNH} 4-\mathrm{N} / \mathrm{m}^{2} / \mathrm{d}$

According to the studies carried out (by Zimmo et al., 2003) the maximum and the minimum nitrification rate for the algae based pilot scale ponds considering all seasons (depth $0.9 \mathrm{~m}$ and surface area $3 \mathrm{~m}^{2}$ ) was 623 to $204 \mathrm{mgNH}_{4}-\mathrm{N} / \mathrm{m}^{2} / \mathrm{d}$
The effect of having biofilm supports compared to above literature $=15555 / 623=25$

Table 4 below shows the nitrification rate achieved in different ponds compared to the performance of the lab scale pond

However, it should be noted that the batch tests were conducted on fully lighted conditions with biofilm only on one side, which received full light intensity. In the lab scale pond it may not be the same throughout the depth but the DO was sufficiently available to enhance nitrification. Alternatively, the thickness of the biofilm is higher near the inlet and progressively reduced along the plug flow reactor.

Table 4 Comparison of nitrification rate with full scale ponds

\begin{tabular}{|c|c|c|c|c|}
\hline Pond site & $\begin{array}{c}\text { Load } \\
\text { (kg BO } \\
\text { D/ha/ } \\
\text { day) }\end{array}$ & $\begin{array}{c}\text { Temp. } \\
\text { ( } \mathrm{C} \text {. }\end{array}$ & \begin{tabular}{|c|} 
Total \\
Nitrogen \\
removal \\
(mg/m² \\
/day)
\end{tabular} & $\begin{array}{c}\text { Compari- } \\
\text { son of } \\
\text { nitrifi- } \\
\text { cation } \\
\text { rate with } \\
\text { this rese- } \\
\text { arch }\end{array}$ \\
\hline $\begin{array}{l}\text { Missouri, } \\
\text { USA }\end{array}$ & 45 & $2-33$ & 2560 & 6.1 \\
\hline $\begin{array}{l}\text { Missouri, } \\
\text { USA }\end{array}$ & 67 & $2-33$ & 3840 & 4.1 \\
\hline $\begin{array}{l}\text { Missouri, } \\
\text { USA }\end{array}$ & 112 & $2-33$ & 6400 & 2.4 \\
\hline $\begin{array}{l}\text { Paraiba, } \\
\text { Brazil }\end{array}$ & 80 & 25 & 1320 & 11.8 \\
\hline $\begin{array}{l}\text { Nagpur, } \\
\text { India }\end{array}$ & 450 & 29 & 5620 & 2.8 \\
\hline $\begin{array}{l}\text { Madras, } \\
\text { India }\end{array}$ & 206 & 30 & 2600 & 6.0 \\
\hline $\begin{array}{l}\text { California, } \\
\text { USA }\end{array}$ & $\begin{array}{l}\text { Deep } \\
\text { ponds }\end{array}$ & & 2500 & 6.2 \\
\hline
\end{tabular}

Source: Árceivala, 1981

However, with increasing exposure time the thickness of the biofilm along the reactor was observed to be increasing and may be stable with longer exposure time. The above calculation was based on the average nitrification rate of the twelve batch incubations carried out. 
The influent NH4-N concentration in this study and the concentration used by Zimmo et al., (2003) both fall around $60 \mathrm{mg} / 1$.

- Nitrification rate $\left(\mu \mathrm{gNH} \mathrm{A}_{4}-\mathrm{N} / \mathrm{cm}^{2} / \mathrm{h}\right)$ :

It was possible to achieve an average nitrification rate of $11.6 \mu \mathrm{gNH}_{4}-\mathrm{N} / \mathrm{cm}^{2} / \mathrm{h}$ during the batch test. These rates are quite high compared to rates achieved by McLean et al., (2000) which is $3-4 \mu \mathrm{gNH}_{4}-\mathrm{N} / \mathrm{cm}^{2} / \mathrm{h}$ achieved in pilot scale ponds in Australia with depth varied up to $500 \mathrm{~mm}$. The influent Ammonium concentration to these ponds was in the range of $40 \mathrm{mg} / 1$. This difference between the nitrification rates may be due to fact that pilot scale pond influent characteristics will not be consistent, depth of immersion of biofilm plates are quite deeper compared to the depth used in this study and the environmental conditions such as wind, turbulence, sunlight etc are different from the lab scale ponds. When the depth of biofilm plate is more, due to the limited sunlight penetration, $\mathrm{DO}$ will be available only on the top part due to algal photosynthesis, hence the top part is able to nitrify effectively. However, when the depth increases then the available DO will also drop creating conditions favourable for denitrification. For attached growth processes, substrate is consumed within a biofilm.

The bulk liquid DO concentration that must be present, so that nitrification rate in the biofilm is not limited, due to the surface flux rate of Oxygen is tabulated below;

Table 5. Bulk liquid DO concentration necessary to prevent an Oxygen flux limitation for nitrification

\begin{tabular}{|c|c|}
\hline $\begin{array}{c}\text { Bulk liquid } \mathrm{NH}_{4}-\mathrm{N} \\
\text { concentration, } \mathrm{g} / \mathrm{m}^{3}\end{array}$ & $\begin{array}{c}\text { Bulk liquid DO } \\
\text { concentration, } \mathrm{g} / \mathrm{m}^{\mathbf{3}}\end{array}$ \\
\hline 1.0 & 2.8 \\
2.0 & 5.6 \\
3.0 & 8.4 \\
\hline
\end{tabular}

Source: Metcalf \& Eddy, 2003

According to the above table the bulk liquid DO concentration compared to the $\mathrm{NH}_{4}-\mathrm{N}$ concentration present in the lab scale ponds as well as batch incubations have values less than the values given in the above table.
Therefore, nitrification rate in the biofilm is limited by surface flux rate of Oxygen at least to some extent.

According to research carried out by Craggs et al., (2000), he achieved 4.2 to $9.0 \mu \mathrm{gNH}_{4}-\mathrm{N} /$ $\mathrm{cm}^{2} / \mathrm{h}$ for dairy farm waste facultative ponds in New Zealand with culture medium under controlled conditions $\left(20^{\circ} \mathrm{C}, \mathrm{pH}=7\right.$ and constant stirring, DO 2-3mg/l, dark). The nitrification potentials were determined by measuring the rate of ammoniacal- $\mathrm{N}$ removal in bioassays of a biofilm-coated surface with $200 \mathrm{ml}$ of either ammonical $-\mathrm{N}$ spiked $(\mathrm{NH} 4 \mathrm{Cl})$ pond surface water or culture medium (both $50 \mathrm{~g} \mathrm{~N} / \mathrm{m}-3$ ).

These results are much closer to the results achieved in this study but most of the above parameters were allowed to change along with biological activities that prevailed in the batch incubations.

- Nitrogen mass balance:

The average nitrification rate achieved for blanks and biofilm reactors were 230.6 and $385.9 \mathrm{mg} \mathrm{NH} 4+-\mathrm{N} / \mathrm{m}^{2} / \mathrm{d}$ respectively. This figure is much less than the nitrification rate obtained from the batch test. This may be due to the limitation of bulk liquid DO concentration present in the reactors having limited nitrification rate.

- Trend in NH4+-N removal when biofilm plates exposed for different $\mathrm{NH4+-N}$ concentrations:

The $g$ NH4+-N/gDS/d increased up to NH4+-N concentration of $25 \mathrm{mg} / 1$. Representing NH4+-N/gDS/d instead of $\mu \mathrm{g}$ $\mathrm{NH} 4+-\mathrm{N} / \mathrm{cm}^{2} / \mathrm{h}$ gives a better comparison as dry solids represent the biomass directly responsible for nitrification.

According to Figure 3 it is clear that the Nitrification rate per biomass follows a similar pattern to that of Nitrobacter with some deviation mainly due to difference in gradient and initial NH4+-N concentration. This difference may be due to the fact that biomass in this experiment contained fibre and algae in addition to bacteria. 
Table 6. Eliminating the effect/activities of blank plate

\begin{tabular}{|c|c|c|c|c|c|}
\hline $\begin{array}{c}\text { Initial } \\
\text { NH4-N } \\
(\mathrm{m} / \mathrm{l})\end{array}$ & $\begin{array}{c}\text { Nitrifica- } \\
\text { tion rate } \\
\text { row } 1 \text { ( } \mathrm{\mu g} \\
\mathrm{NH}_{4}-\mathrm{N} / \\
\left.\mathrm{cm}^{2} / \mathrm{h}\right)\end{array}$ & $\begin{array}{l}\text { Nitrifi- } \\
\text { cation } \\
\text { rate row } \\
2(\mu g N H 4 \\
-\mathrm{N} / \mathrm{cm} 2 / \mathrm{h})\end{array}$ & $\begin{array}{l}\text { Nitrifica- } \\
\text { tion rate } \\
\text { row } 3 \text { ( } \mathrm{gg} \\
\mathrm{NH4}-\mathrm{N} / \\
\left.\mathrm{cm}^{2} / \mathrm{h}\right)\end{array}$ & $\begin{array}{c}\text { Avg } \\
(\mu g N H \\
4-\mathrm{N} / \\
\mathrm{cm} / \mathrm{h})\end{array}$ & SD \\
\hline 10 & 1.5 & 3.8 & 4.1 & 3.1 & 1.4 \\
\hline 25 & 8.1 & 10.5 & 9.3 & 9.3 & 1.2 \\
\hline 60 & 25.5 & 21.7 & 20.3 & 22.5 & 2.7 \\
\hline Avg & 11.7 & 12 & 11.6 & 11.6 & 0.2 \\
\hline $\begin{array}{l}\text { With } \\
\text { inhibi- } \\
\text { tor }\end{array}$ & 6.8 & 5.4 & 10.5 & 7.6 & 2.6 \\
\hline
\end{tabular}

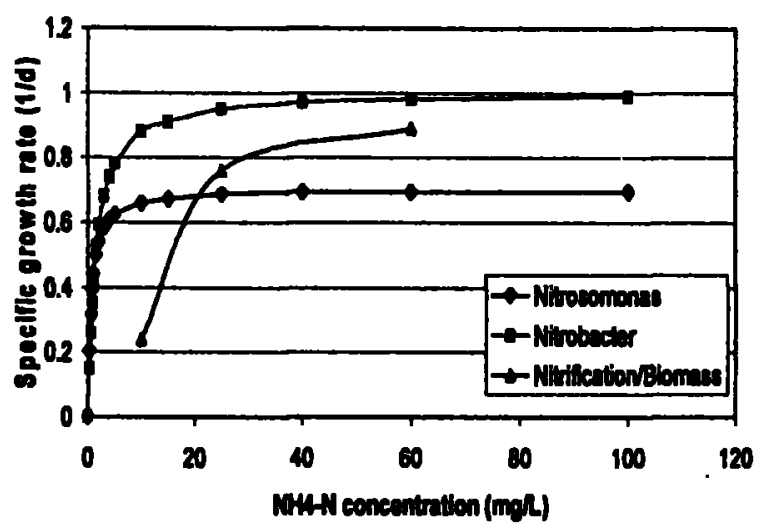

Figure 3. The graph of Specific growth rate Vs NH4-N Concentration

Growth curve for Nitrosomona and Nitrobactor for the suspended growth nitrification process (pure culture) with nitrification rate/biomass/day

Source: Metcalf \& Eddy, 2003

In this kind of biofilm experiment the nitrification rate is mainly controlled by two factors. The first one is the diffusion of $\mathrm{NH} 4+-\mathrm{N}$ in to the biofilm, which will be governed by the thickness of the biofilm, i.e. competition for the NH4+-N between the nitrifiers in the outer layers and the inner layers. The second factor will reflect the ability of the nitrifying bacteria to nitrify the NH4+-N.

- Batch test procedure adopted:

The simple batch test procedure adopted in this study proves to be a convenient way to carryout batch tests to determine nitrification rate. Saturation of artificial wastewater and demineralised water with $\mathrm{DO}$ before mixing to form the desired initial NH4+-N concentration provided adequate $\mathrm{DO}$ to keep the biofilm aerobic for $\mathbf{8}$ hour exposure time and not to retard nitrification process.

\section{- Biofilm studies:}

Olympus BX 51 microscope with DP12 attachment was able to take digital pictures to carryout basic identification under $\mathbf{4 0 0}$ times magnification.

\section{Conclusions}

When biofilm that developed on the side walls/ bottom at Blank2 was cleaned and the reactor put back into operation, with the same wastewater the Ammonium removal dropped considerably due to absence of biofilm on sidewalls. This is mainly due to the fact that the lab scale pond has low volume to area ratio compared to full scale or pilot scale ponds resulting with growth of biofilms on walls and base (due to shallow depth allowing full light penetration) in addition to the biofilm development on biofilm supports.

- The effect of having biofilm supports in lab scale pond compared to pilot scale and full scale WSP found in literature was encouraging. In this study the average nitrification rate achieved for the batch test proved to be 25 times higher than the rate achieved by Zimmo et al., (2003) in his algae based pilot scale ponds for the maximum nitrification considering all seasons. According to Table 4, compared to full-scale ponds, the research values achieved are 2 to 11 times higher. Further, in this study, it was possible to achieve NH4-N removal efficiency ranging from $56 \%$ to $65 \%$ and $C O D$ removal of $30 \%$ to $33.5 \%$.

- An average nitrification rate of $11.6 \mu \mathrm{gNH} 4 \mathrm{~N} /$ $\mathrm{cm} 2 / \mathrm{h}$ was possible during the twelve batch incubations carried out. This figure is slightly higher compared to literature (Refer Table 6)

- $\mathrm{gNH} 4+-\mathrm{N} / \mathrm{gDS} / \mathrm{d}$ achieved in batch test against varying initial $\mathrm{NH4+-N}$ concentration shows that this curve follows a similar pattern to the growth curve of Nitrobacter with some deviations. 
- Simple procedure proposed to determine nitrification for batch test proved satisfactory.

- It can be concluded that substantial improvement of Nitrogen removal can be possible in WSP by immersing biofilm support material considering the results obtained from this pilot scale ponds.

- The main advantage of this study to the industry is that by providing Bio film support material it will improve the Nitrogen removal as well as significant reduction in pond area requirement that can be achieved when constructing/augmenting waste stabilisation ponds.

\section{References}

(1) Arceivala S. J., 1981, Wastewater treatment and disposal, Engineering and ecology in pollution control, Marcel Dekker, Inc, New York, pp 787859.

(2) Barnes D. and Bliss P.J. (1983). Biological control of nitrogen in wastewater. treatment. $E$ and $F . N$. Spon, London, UK. 3pp.

(3) Cragg R.J., Tanner C.C., Sukias J.P.S., and Davies-Colley R.J., 2000, Nitrification potential of attached biofilms in dairy farm waste stabilization ponds, Wat. Sci. Tec., 42 (10-11), 195202

(4) Gijzen H. J. and Ikramulla M (1999). Prefeasibility of duckweed-based wastewater treatment and resource recovery in Bangladesh. World Bank Report, Washington D.C., pp194.

(5) Gijzen H.J. and Mulder A. (2001). The nitrogen cycle out of balance. Water21, August 2001, Pp.38-40.

(6) Gunatilleke D. N. De S., 2005, Improvement of Nitrogen Removal in Waste Stabilization Ponds, M.Sc. Thesis (SE07), UNESCO-International Institute for Infrastructural Hydraulics and Environmental Engineering, Delft.

(7) Horne A. J. (1995). Nitrogen removal from waste treatment pond or activated sludge plant effluent with free- surface wetlands. Wat. Sci. Tech. 31:341-351.

(8) Horne A. J. and Goldman C. R. (1994). Limnology. McGraw-Hill, New York. Second Edition, 627 pp.

(9) Lubberding, H.J., 2003, Microbiology, unpublished lecture notes, UNESCO. International Institute for Infrastructural Hydraulic and Environmental Engineering, Delft. .
(10) McLean B.M. , Baskaran K. and Connor M.A. , 2000, The use of algal-bacterial biofilms to enhance nitrification rates in lagoons: experience under laboratory and pilot - scale conditions. Wat. Sci. Tec., 42 (10-11), 187-194.

(11) Metcalf \& Eddy, Inc. 2003. Wastewater Engineering: Treatment and Reuse, McGraw Hill Publishing Co. New York.

(13) Standard Methods for examination of Water and Wastewater Analysis, 1999, 18 Edition, AWWA.

(14) World Health Organization (WHO), 2003, Looking back: Looking ahead, Five decades of challenges and achievements in environmental sanitation and health, Geneva.

(15) Zimmo O., 2003, Nitrogen Transformation and Removal Mechanisms in Algal and Duckweed Waste Stabilization Ponds, A. A. Balkema Publisers, Lisse, PhD Thesis. 